\title{
Red and Far-red Light Treatments to Modify Thermoinhibition, Photoblasticity, and Longevity in Lettuce Seeds
}

\author{
Isabel Pimentel and Samuel Contreras ${ }^{1}$
}

ADDITIONAL INDEX wORDs. Lactuca sativa, light-emitting diode, photosensitivity, phytochrome, seed water content, storability

Summary. Germination in lettuce (Lactuca sativa) seeds can be inhibited by high temperatures (thermoinhibition) or darkness (positive photoblasticity). Priming is commonly used as a seed treatment to avoid these problems. However, this treatment is complicated, expensive and has detrimental effect on seed longevity. The objectives of this study were to 1 ) develop a simple alternative treatment to priming, based on red light irradiations and 2) to develop a treatment to extend seed longevity. Lettuce seeds from cultivars Tango, Milanesa, Ideal Cos, and Gallega de Invierno were partially hydrated in containers with $98 \%$ relative humidity (RH) and irradiated with red (R) light for 24 hours, or far-red (FR) light for 216 hours. Throughout the treatment, seeds reached $16 \%$ water content and, once finished, they were dried with air at $30{ }^{\circ} \mathrm{C}$. Untreated (control) and primed seeds were also evaluated. Germination was evaluated in light and darkness at temperatures between 12 and $36^{\circ} \mathrm{C}$ in a thermogradient table. Effects in longevity were estimated by evaluating germination after various aging periods at $45^{\circ} \mathrm{C}$ and $75 \% \mathrm{RH}$. The R-light treatment improved germination in the dark at temperatures up to $25^{\circ} \mathrm{C}$, but did not have a significant effect on seed germination under light. Germination after accelerated aging showed that R- and FR- light treatments extended seed longevity when compared with control seeds. Therefore, this effect would not be associated to photoblasticity alleviation or imposition.

Primed seeds deteriorated faster than the control. Compared with priming, the Rlight treatment was simpler and improved seed longevity. However, priming effects on alleviation of seed photoblasticity and thermoinhibition at temperatures over $25{ }^{\circ} \mathrm{C}$ were greater.

L

ettuce, one of the most important vegetable crops in the world, is established through direct sowing or the transplant of seedlings; in both cases, high seed quality is essential to achieve a successful crop as low or slow germination results in poor and irregular plant populations (Smith et al., 1973). However, seeds of many lettuce cultivars present thermoinhibition (reduction of germination at temperatures over $25^{\circ} \mathrm{C}$ ) and/or positive photoblasticity (requirement of light for germination); two types of physiological dormancy that may delay and reduce field emergency, especially when sown in warm environments (Nascimento, 2003; Wien, 1997). Seed priming, a treatment of controlled seed hydration and drying, has proved to reduce lettuce seed photoblasticity and

Departamento de Ciencias Vegetales, Pontificia Universidad Católica de Chile, Vicuña Mackenna 4860, Santiago 7820436, Chile

This research was financed by Fondecyt project no. 11100122 , year 2010 .

We thank José Antonio Alcalde and Andrés Schwember for contribution in manuscript preparation.

${ }^{1}$ Corresponding author. E-mail: scontree@uc.cl. thermoinhibition, improving speed and uniformity of emergence (Sung et al., 2008; Valdes and Bradford, 1987). However, an undesired consequence of priming is reduced seed longevity (Chojnowski et al., 1997; Powell et al., 2000; Tarquis and Bradford, 1992). In addition, protocols for the treatment usually are specific to each genotype and lot, and the application of a wrong protocol may cause a reduction in seed quality (Capron et al., 2000; Coolbear et al., 1992). As a result, priming treatments are usually expensive, need to be carried out by specialized companies, and are not available for farmers of many countries. Consequently, the development of a simpler treatment, able to improve seed germination under unfavorable conditions without affecting seed longevity, is highly desirable.

Given that germination of photoblastic lettuce seeds is under light control, this stimulus may be managed to promote or retard germination. Red light promotes germination in positive photoblastic lettuce seeds, while FR may inhibit germination and induce secondary dormancy in lots that did not have positive photoblasticity (Contreras et al., 2008; Górski et al., 2013; Kendrick and Russell, 1975). Seeds sense light through phytochromes, proteins that may be found in two interconvertible forms: the R-light absorbing form $(P r)$ and the FR-light absorbing form $(P f r) ; P r$ converts to Pfr when absorbs R-light, while $P f r$ converts to $P r$ after absorption of FR-light. $P f r$ is the biologically active form and a high $P f r$ to $P r$ ratio in positive photoblastic seeds will trigger germination (Kendrick and Russell, 1975; Seo et al., 2009). Different studies suggest that seeds matured in environments with higher $\mathrm{R}$ to $\mathrm{FR}$ ratio (R:FR), such as in direct sun light, will have a higher fraction of $P f r$ when dry, thus germinating better in darkness than seeds matured in environments with lower R:FR, such as under canopy of neighboring plants (Contreras et al., 2009; Cresswell and Grime, 1981; Hayes and Klein, 1974). Contreras et al. $(2008,2009)$ compared seeds produced in environments with contrasting light quality and observed that lettuce seeds developed in the environment with the higher R:FR ratio showed lower photoblasticity, thermoinhibition, and longevity. These authors observed that the effect of light environment in seed dormancy and longevity was produced at the last part of seed development, during the phase of maturation and drying, when seed decreases its water content from $40 \%$ to $8 \%$.

\begin{tabular}{llll}
\hline $\begin{array}{l}\text { Units } \\
\begin{array}{l}\text { To convert U.S. to SI, } \\
\text { multiply by }\end{array}\end{array}$ & U.S unit & SI unit & $\begin{array}{l}\text { To convert SI to U.S., } \\
\text { multiply by }\end{array}$ \\
\hline 0.1 & bar & $\mathrm{MPa}$ & 10 \\
29.5735 & $\mathrm{fl} \mathrm{oz}$ & $\mathrm{mL}$ & 0.0338 \\
2.54 & inch $(\mathrm{es})$ & $\mathrm{cm}$ & 0.3937 \\
25.4 & inch $(\mathrm{es})$ & $\mathrm{mm}$ & 0.0394 \\
305.1517 & $\mathrm{oz} / \mathrm{ft}^{2}$ & $\mathrm{~g} \cdot \mathrm{m}^{-2}$ & 0.0033 \\
$\left({ }^{\circ} \mathrm{F}-32\right) \div 1.8$ & ${ }^{\circ} \mathrm{F}$ & ${ }^{\circ} \mathrm{C}$ & $\left({ }^{\circ} \mathrm{C} \times 1.8\right)+32$
\end{tabular}


In addition to reports in lettuce by Contreras et al. (2008, 2009), a relationship between seed photoblasticity and longevity has been observed in several other species. Górski and Rybicki (1985) reported that treating seeds of loose silky bentgrass (Apera spica-penti), redroot pigweed (Amaranthus retroflexus), and prickly lettuce (Lactuca serriola) with FR light induced dormancy and prolonged longevity of soil-buried seeds. In a similar experiment, Doroszewski (1997) observed improvement of longevity in FR-treated seeds in five of six species studied. More recently, Górski et al. (2013) reported that lettuce seeds of cultivar Cud Vorburgu treated with FR-light acquired secondary dormancy and had a significantly extended longevity when compared with untreated seeds, both stored at room temperature in dark. Despite these observations, it remains unclear if there is a cause-effect relationship between seed photoblasticity and longevity. A treatment to increase seed longevity would be useful to gene banks, seed companies, and seed users in general, so is a matter that deserve been studied.

Because the photoconversion reaction in lettuce seeds takes place with a minimum seed water content close to $8 \%$ (Vertucci et al., 1987), we hypothesize that treatment of these seeds with R-light should decrease in photoblasticity and improve germination. Accordingly, the first objective of this study was to develop an alternative treatment to priming based on irradiation with R-light of seeds with controlled water contents. Since this can be achieved at lower seed water contents, this treatment should be simpler, less risky, and with a lower impact in seed longevity than priming. Additionally, a cause effect relation has been suggested between seed photoblasticity and longevity; therefore, we hypothesize that treating seeds with FR-light should be effective to induce photoblasticity and improve longevity, and the second objective was to develop a treatment to increase seed longevity based on irradiation with FR-light.

\section{Materials and methods Plant material}

Four lettuce cultivars were used in this study: Tango cutting lettuce (Lactuca sativa var. acephala), Ideal
Cos cos lettuce (L. sativa var. longifolia), and Gallega de Invierno and Milanesa butterhead lettuce ( $L$. sativa var. capitata). Seed was obtained by self-production and used within 1 year from harvest. The amount of 'Milanesa' seed was restricted, so this cultivar was not included in some of the evaluations.

Expt. 1. Protocol DeterminaTION FOR LIGHT TREatments. Preliminary tests were conducted to choose the best light treatment for improvement of lettuce seed quality, with RH and treatment durations selected from the best alternatives evaluated in prior experiments (Pimentel, 2013). The general protocol consisted of placing seeds inside a transparent plastic container $(330 \mathrm{~mL})$ with $98 \% \mathrm{RH}$, under a known source of light for a determined time (Fig. 1). Inside each container, a saturated potassium sulfate $\left(\mathrm{K}_{2} \mathrm{SO}_{4}\right)$ solution was used to reach equilibrium of $98 \% \mathrm{RH}$ (Winston and Bates, 1960). Seeds were placed on a grid that prevented their contact with the salt solution (Fig. 1). Following the light exposure, seeds were taken to a $30{ }^{\circ} \mathrm{C}$ air dryer for $90 \mathrm{~min}$ and then stored in hermetic plastic bags at $20^{\circ} \mathrm{C}$ until evaluation.

Light-emitting diodes (LED) were used for the R-light seed conditioning, with a R:FR of 140 and 6 $\mu \mathrm{mol} \cdot \mathrm{m}^{-2} \cdot \mathrm{s}^{-1}$ photosynthetically active radiation (PAR). The $P A R$ and R:FR quantifications were determined using a portable light meter (LI-250A; LICOR Biosciences, Lincoln, NE) and a light meter (SpectroSence 2; Skye Instruments, Llandrindod Wells, UK) with a $660 / 730$ sensor (SKR 110, Skye Instruments), respectively. Rlight treatments were carried out in a $20{ }^{\circ} \mathrm{C}$ room over a fabric covered shelf to avoid the possible interference of other light sources.

To determine the appropriate treatment duration, 'Tango' seeds were exposed for 24 and 144 h to $\mathrm{R}$ light at 98\% RH; physiological seed germination was evaluated in dark at different temperatures.

To evaluate if other light source and temperature led to the same results as the $\mathrm{R}$ light at $20{ }^{\circ} \mathrm{C}$ treatment, irradiations with $\mathrm{R}$ and fluorescent light at different temperatures were performed in 'Tango', 'Ideal Cos', and 'Gallega de Invierno'. For fluorescentlight treatments, fluorescent tubes with $2.8 \mathrm{R}: F R$ and $13 \mu \mathrm{mol} \cdot \mathrm{m}^{-2} \cdot \mathrm{s}^{-1} P A R$ were used. Seeds were treated for $24 \mathrm{~h}$ and $98 \% \mathrm{RH}$ in a $20{ }^{\circ} \mathrm{C}$ growth chamber or at room temperature $(28$ ${ }^{\circ} \mathrm{C}$ average, with 25 and $31{ }^{\circ} \mathrm{C}$, minimum and maximum, respectively). Two replications of 200 seeds each were used per cultivar. Physiological seed germination was evaluated in dark at $25^{\circ} \mathrm{C}$.

EXPT. 2. R-Light TREATMENT AS ALTERNATIVE TO IMPROVE GERMINATION. Seeds were treated with $\mathrm{R}$ light for $24 \mathrm{~h}$ at $20{ }^{\circ} \mathrm{C}$ and $98 \%$ RH. Three replications of 400 seeds of 'Milanesa' and four replications of 700 seeds of 'Tango', 'Ideal Cos', and 'Gallega de Invierno' were used. The experimental unit corresponded to single containers, which were arranged in a completely randomized design.

\section{Priming}

Protocol for priming was adapted from Schwember and Bradford (2005). Seeds were treated in 9-cmdiameter petri dishes with three filter papers $\left(90 \mathrm{~mm}, 87 \mathrm{~g} \cdot \mathrm{m}^{-2}\right.$; Munktell Filter, Falun, Sweden) with $10 \mathrm{~mL}$ of a polyethylene glycol [PEG (PEG 8000, Sigma-Aldrich, St. Louis, $\mathrm{MO})$ ] solution at $\psi_{\mathrm{S}}$ of $-1.25 \mathrm{MPa}$ and then sealed with laboratory film (parafilm M; Bemis Flexible Packaging, Neenah, WI). The PEG concentration was calculated according to the formula proposed by Michel (1983). Dishes with seeds were taken to a $20^{\circ} \mathrm{C}$ room with fluorescent light for $48 \mathrm{~h}$. Then, seeds were rinsed with distilled water and dried for $90 \mathrm{~min}$ in a $30{ }^{\circ} \mathrm{C}$ air dryer. Each dish represented an experimental unit and there were four replications arranged in a completely randomized design.

Physiological germination of control (untreated) and treated seeds was evaluated at a range of temperatures $\left(12\right.$ to $36{ }^{\circ} \mathrm{C}$ ) in light or darkness.

Expt. 3. FR-Light TREATMENT TO IMPROVE SEED LONGEVITY. Seeds were exposed to FR light during $216 \mathrm{~h}$ at $20^{\circ} \mathrm{C}$ and $98 \% \mathrm{RH}$. Source of FR light corresponded to a LED lighting system (SNAP-LITE; Quantus Devices, Barneveld, WI) with 0.039 $\mathrm{R}: \mathrm{FR}$ and $0.1 \mu \mathrm{mol} \cdot \mathrm{m}^{-2} \cdot \mathrm{s}^{-1} P A R$. The containers were kept in a fabric covered box to avoid the entrance of light with different wavelength. The light source was at the top of the box. Three replications were used for 'Milanesa' and four for 'Tango', 


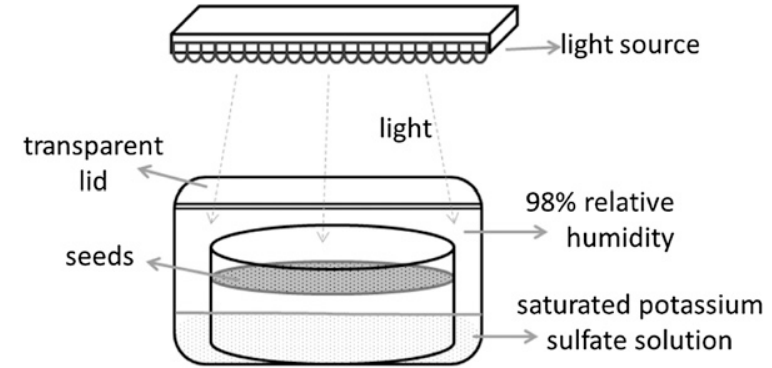

Fig. 1. General outline of light seed treatment. Inside the container, lettuce seeds reached an equilibrium water content of $16 \%$. Light was provided by red $(660 \mathrm{~nm})$ or far-red $(730 \mathrm{~nm})$ light-emitting diodes.

'Ideal Cos', and 'Gallega de Invierno'; the experimental unit corresponded to single containers that were completely randomized inside the box. After light treatment, the drying process was conducted in darkness. Priming and Rlight treatments were conducted as described in Expt. 2. Longevity of control and treated seeds was evaluated as described below.

\section{Seed evaluation}

EQUilibrium SEED WATER CONTENT DETERMINATION. Four replications of about $1 \mathrm{~g}$ of 'Tango' seed were placed in containers with $98 \%$ $\mathrm{RH}$. After $18 \mathrm{~h}$, seeds were weighed and dried in an oven at $103{ }^{\circ} \mathrm{C}$ for 17 $\mathrm{h}$, followed by $30 \mathrm{~min}$ in a desiccator with silica gel, and finally reweighed; percentage of seed water content was calculated on a fresh weight basis according with rules of the International Seed Testing Association (ISTA, 2011).

Physiological germination. For each replication, physiological germination (radicle emergence) was evaluated for 20 to 25 seeds placed in $5-\mathrm{cm}$-diameter petri dishes over three layers of filter paper saturated in distilled water. Evaluations were performed in light or darkness at a range of temperatures from 12 to $36{ }^{\circ} \mathrm{C}$, provided by a thermogradient table, or growing chambers at constant temperatures of 20 and $25^{\circ} \mathrm{C}$. Germination in dark was performed using aluminum-foil-covered petri dishes. When evaluated in light, germination was recorded daily for $7 \mathrm{~d}$, while in dark just one evaluation was performed $4 \mathrm{~d}$ after sowing. A germination index was calculated for evaluations in light according to the following equation (adapted from Maguire, 1962): GI = (ratio of germinated seeds day 1$) / 1+\ldots($ ratio of germinated seeds day X)/X...+ (ratio of germinated seeds day 7)/7.

SEED LONGEVITY. Salt-saturatedaccelerated aging (SSAA) was carried out to estimate seed longevity. Seeds were placed in hermetically closed 330-mL square plastic containers with saturated sodium chloride $(\mathrm{NaCl})$ solution $(75 \% \mathrm{RH})$ at $45^{\circ} \mathrm{C}$ in a waterjacketed incubator (model 3015, Sheldon Manufacturing, Cornelius, OR). per replication were placed over an aluminum plate placed on a grid, so contact between seeds and salt solution was avoided. After aging, standard germination was evaluated at $20^{\circ} \mathrm{C}$ and light in 25 to 50 seeds per replication; normal seedlings were evaluated $7 \mathrm{~d}$ after planting according to ISTA rules (ISTA, 2011).

Data ANALYsis. Seed evaluation results were analyzed with an analysis of variance. When significant differences among treatments $(P<0.05)$ existed, differences were analyzed through a least significant difference test $(\alpha=0.05)$. Before analysis, germination percentages and index were transformed to arcsine of the square root of the proportion of the number.

\section{Results}

EXPT. 1. Moisture content reached by 'Tango' seeds after $18 \mathrm{~h}$ in a closed container at $20{ }^{\circ} \mathrm{C}$ and $98 \%$ $\mathrm{RH}$ was $\approx 16 \%$. Figure 2 shows that 'Tango' seeds treated at $20^{\circ} \mathrm{C}$ for 24 $\mathrm{h}$ with $\mathrm{R}$ light reached higher dark germination percentages than untreated seeds or those treated for $144 \mathrm{~h}$, so subsequent treatment of the seeds were done for $24 \mathrm{~h}$.

Seed treated with fluorescent light and/or at room temperature also presented a significant germination improvement at $25^{\circ} \mathrm{C}$ and dark (Table Inside the container, 100 to 250 seeds
1). However, the magnitude of the effect depended on the cultivar and was lower than that of the treatment using the combination of $\mathrm{R}$ light and $20{ }^{\circ} \mathrm{C}$.

Expт. 2. When evaluated under light at temperatures between 12 and $36{ }^{\circ} \mathrm{C}$, R-light-treated seeds did not improve their germination compared with untreated seeds (Fig. 3). Seeds from all evaluated cultivars reached about $100 \%$ germination at temperatures between 12 and $30^{\circ} \mathrm{C}$; Figure 3 presents results for 'Tango' and 'Milanesa', similar tendencies were observed for 'Ideal Cos' and 'Gallega de Invierno'.

When germination was evaluated on the thermogradient table in darkness, different degrees of positive photoblasticity were observed (Fig. 4). Untreated seeds of 'Tango' did not exceed $20 \%$ germination at their optimum temperature $\left(\approx 21^{\circ} \mathrm{C}\right)$ and were the most sensitive cultivar to the lack of light (Fig. 4A). Untreated seeds of 'Milanesa' and 'Gallega de Invierno' germinated over $80 \%$ at $21{ }^{\circ} \mathrm{C}$, but decreased significantly at lower or higher temperatures (Fig. 4B and D). 'Ideal Cos' seeds showed the lower photoblasticity, they reached about $100 \%$ germination from 12 to $21^{\circ} \mathrm{C}$, but germination decreased thereafter (Fig. 4C). R-light treatments had a positive effect in photoblasticity alleviation, which was more marked in 'Tango' seeds (Fig. 4A), and less in 'Ideal Cos' (Fig. 4C). However, the effect of priming in alleviation of photoblasticity was greater than that of $\mathrm{R}$-light treatment in the four evaluated cultivars (Fig. 4).

ExPT. 3. After 5 and $7 \mathrm{~d}$ of SSAA, untreated and light ( $\mathrm{R}$ or FR) treated seeds performed better than the primed seeds, producing a significantly higher percentage of normal seedlings (Table 2). In 'Tango', light treated seeds produced higher percentages of normal seedlings than untreated seeds; however, these differences were not significant. 'Ideal Cos' seeds that received light treatments had a significantly better performance than the control ones after 5 and $7 \mathrm{~d}$ of SSAA, while in 'Gallega de Invierno', this difference was evidenced after $7 \mathrm{~d}$ of SSAA (Table 2).

Figure 5 shows the decrease of physiological germination percentages in treated and untreated seeds of 'Tango', 'Gallega de Invierno', and 


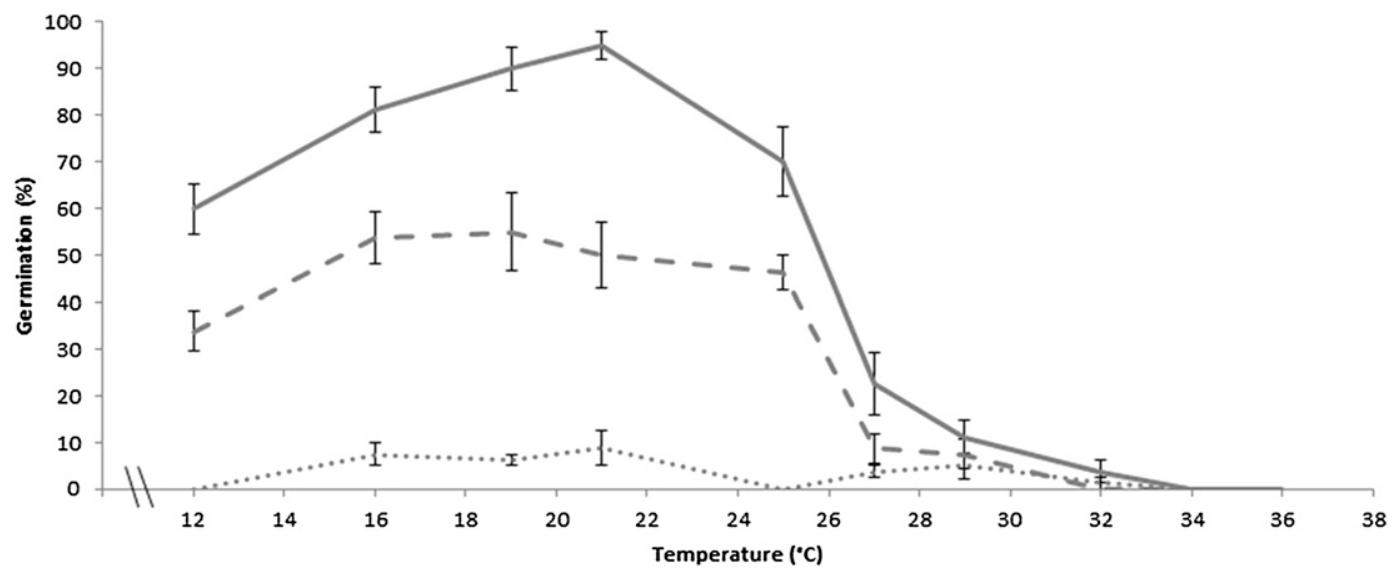

Fig. 2. Percentage of germination in dark at different temperatures of 'Tango' lettuce seeds untreated (dotted line) or treated with red light at $20^{\circ} \mathrm{C}$ and $98 \%$ relative humidity for $24 \mathrm{~h}$ (solid line) or $144 \mathrm{~h}$ (broken line). Data are the mean \pm SE from four replicates of 20 seeds each; $\left(1.8 \times{ }^{\circ} \mathrm{C}\right)+32={ }^{\circ} \mathrm{F}$.

Table 1. Percentage of germination in dark at $25^{\circ} \mathrm{C}\left(77.0^{\circ} \mathrm{F}\right)$ of lettuce seed from three cultivars after different treatments for $24 \mathrm{~h}$ at $98 \%$ relative humidity and red or fluorescent light at constant $20{ }^{\circ} \mathrm{C}\left(68.0^{\circ} \mathrm{F}\right)$ or room temperature.

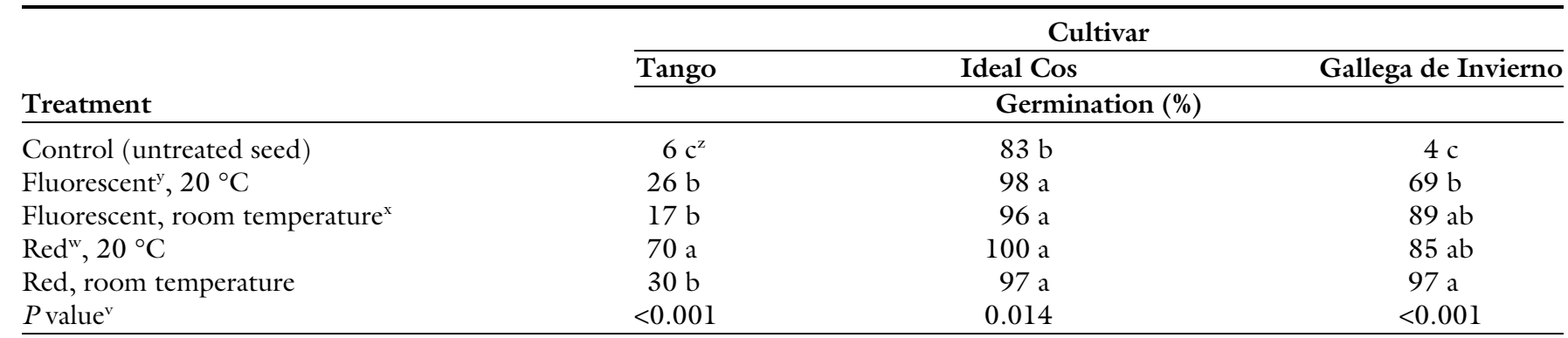

${ }^{2}$ Means in the same column with different letter(s) are significantly different according to least significant difference test $(\alpha=0.05)$.

${ }^{y}$ Fluorescent light with red to far-red ratio $(\mathrm{R}: \mathrm{FR})=2.8$.

${ }^{x}$ Room temperature: $28^{\circ} \mathrm{C}\left(82.4^{\circ} \mathrm{F}\right)$ average, $25^{\circ} \mathrm{C}$ minimum and $31^{\circ} \mathrm{C}\left(87.8^{\circ} \mathrm{F}\right)$ maximum.

wed light with R:FR = 140 .

vrobability value from analysis of variance.

'Ideal Cos' after different periods of SSAA. Once again, primed seeds were most affected by the SSAA, followed by untreated seeds. In this evaluation, a "dark treatment" was included, consisting of treating the seeds at 98\% $\mathrm{RH}$ for $24 \mathrm{~h}$ (similar to R-light treatment), but without light. In the three cultivars evaluated, a consistent improvement of longevity was observed in R-light-, FR-light-, and darktreated seeds. Only in 'Tango' seeds, the FR-light treatment was better than the R-light and dark treatment (Fig. 5A).

\section{Discussion}

Thermoinhibition and positive photoblasticity are problems commonly present in many lettuce cultivars (Cantliffe et al., 2000; Wien, 1997). When germinated in light, the four cultivars used in this study were able to reach about $100 \%$ germination at temperatures until $30^{\circ} \mathrm{C}$. However, different levels of positive photoblasticity were observed in the dark (Fig. 4). The proposed R-light treatment did not have an effect when seeds germinated in light (Fig. 3), but a significant improvement of germination in dark was observed (Fig. 4). The magnitude of the R-light-treatment benefit depended on the germination temperature and cultivar, being greater in Tango, the cultivar with the highest level of photoblasticity, and lower in Ideal Cos, genotype with the lowest photoblasticity. When compared with priming, $\mathrm{R}$ light-treatment benefit was similar at germinations in dark between 16 and $25^{\circ} \mathrm{C}\left(29^{\circ} \mathrm{C}\right.$ in the case of 'Ideal Cos'); however, at higher temperatures priming benefit on seed germination surpassed that of $\mathrm{R}$-light treatment. One of the main benefits of priming is increasing germination speed and uniformity, in addition to overcome thermoinhibition in lettuce seeds (Heydecker et al., 1973; Hill, 1999; Valdes et al., 1985); none of these benefits were observed in R-light-treated seeds when germination was evaluated in light, so benefits of R-light treatment would be restricted to photoblasticity alleviation.

Phytochrome photoactivation (i.e., conversion from $\mathrm{Pr}$ to $P f r$ ) is progressively induced by R-light as seed moisture content increases from $8 \%$ to 18\% (Hsiao and Vidaver, 1971; Vertucci et al., 1987). Therefore, 16\% water content reached by lettuce seeds during the R-light treatment at 98\% $\mathrm{RH}$ would be enough to permit this photoactivation, and a higher proportion of $P f r$ in R-light treated seeds 

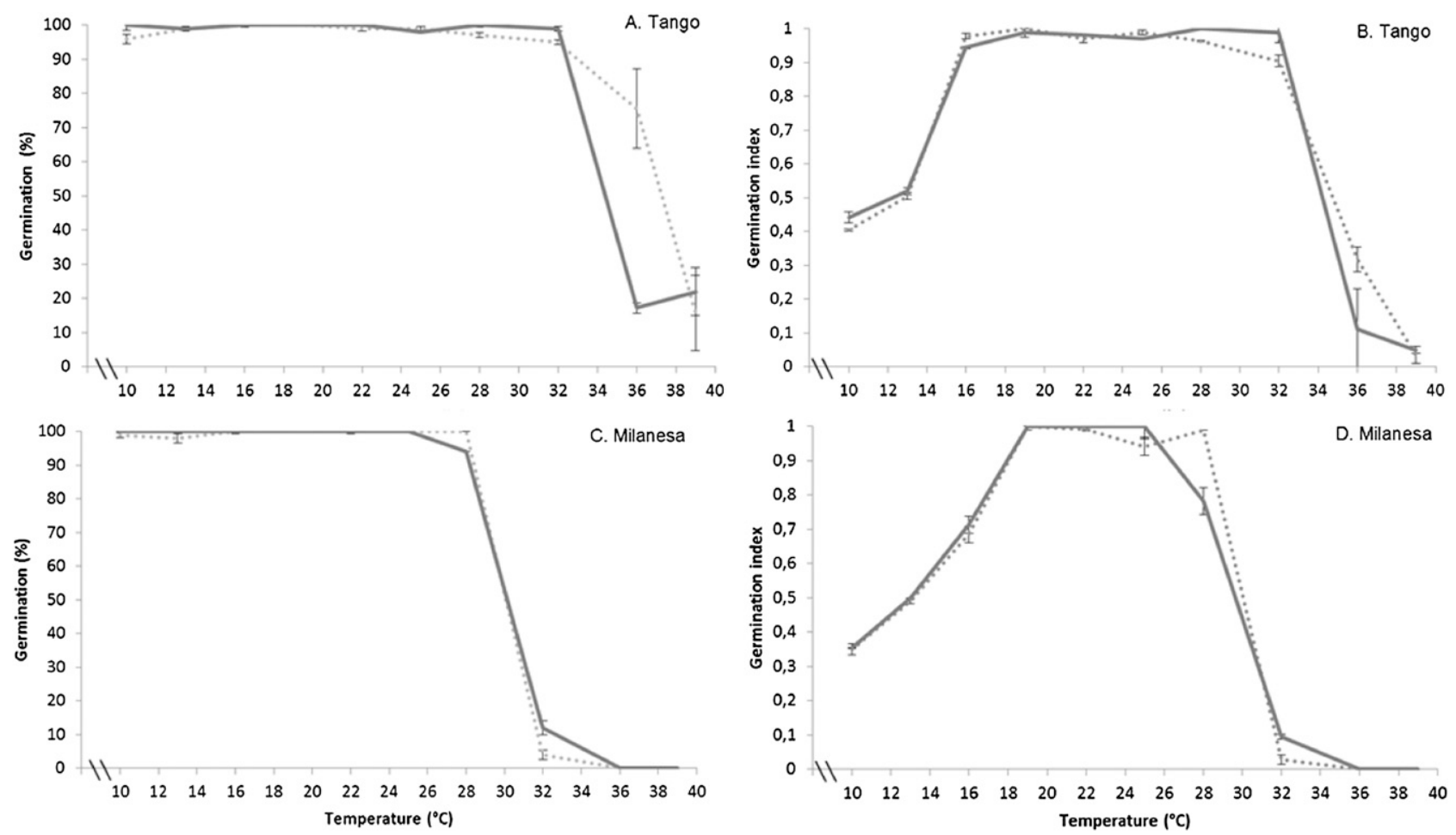

Fig. 3. Germination percentage (A and C) and germination index (B and D) at different temperatures in light of 'Tango' (A and B) and 'Milanesa' ( $C$ and D) lettuce seeds treated with red light during $24 \mathrm{~h}$ at $20{ }^{\circ} \mathrm{C}$ and $98 \%$ relative humidity (solid line) and untreated (dotted line). Data are means \pm SE from four replicates of 20 ('Milanesa') or 25 ('Tango') seeds each; (1.8 $\times{ }^{\circ} \mathrm{C}$ ) $+32={ }^{\circ} \mathrm{F}$.

would explain its improvement of germination in the dark. However, effects of the R-light treatment were limited in comparison with priming, which would be explained by the different water content reached by seeds during each treatment. During priming, seeds reach about a $40 \%$ water content, allowing the occurrence of metabolic processes such as DNA and mitochondrial repair, and transcription and translation of new proteins (Bewley et al., 2013), along with changes in the expression of key genes affecting synthesis of abscisic acid, gibberellins, and ethylene (Schwember and Bradford, 2010), thus favoring germination and alleviation of dormancy. Because of the lower seed water content reached during R-light treatment (16\%), these events would not occur, which may explain why the treatment benefits did not increase when its duration was extended from 24 to $144 \mathrm{~h}$ and the difference of benefits compared with priming. R-light treatment effect would be restricted to conversion of Pr to Pfr.

Advantages that R-light treatments would have over priming are a simpler and less specific protocol, along with a lower or null effect on seed longevity. When light source and temperature were changed in the protocol of the R-light treatment, significant alleviation of photoblasticity at $25^{\circ} \mathrm{C}$ still occurred, but magnitude of the benefit depended on the cultivar (Table 1). Results show that temperature control around $20^{\circ} \mathrm{C}$ and a Rlight source produce better results, although changes in these conditions still improve seed performance.

The effect of seed treatments on seed longevity was estimated by evaluation of germination after different periods of SSAA (Table 2, Fig. 5). As expected, priming showed to increase significantly deterioration rates of treated seeds (Tarquis and Bradford, 1992). R-light-treated seeds presented lower deterioration rates than the control, indicating an improvement in seed longevity. Contreras et al. $(2008,2009)$ found that seeds that completed their development in an environment with a lower R:FR had greater longevity and photoblasticity than seeds maturing at environments with higher R:FR. The authors speculated a possible causeeffect relation between seed photoblasticity and longevity. Additionally, Górski et al. (2013) reported that lettuce seeds imbibed by $6 \mathrm{~d}$ under natural-FR light [light filtered through dense canopy of rhubarb (Rheum rhabarbarum) leaves] acquired secondary dormancy (positive photoblasticity) and presented extended longevity compared with control (nondormant) seeds. On the basis of those results, we hypothesized that irradiation of partially hydrated seeds with FR light would improve its longevity, thus a FR-light treatment was also evaluated. In this case, possible effects should not be limited to $P f r$ conversion, but related to other metabolic events occurring in the seeds, so duration of treatment was extended. However, results showed that the effect of the FR-light treatment, although improved seed longevity, was not different with effect of the R-light treatment (Table $2)$. Therefore, a treatment with no light was incorporated in a new experiment to compare loss of physiological germination capacity after 

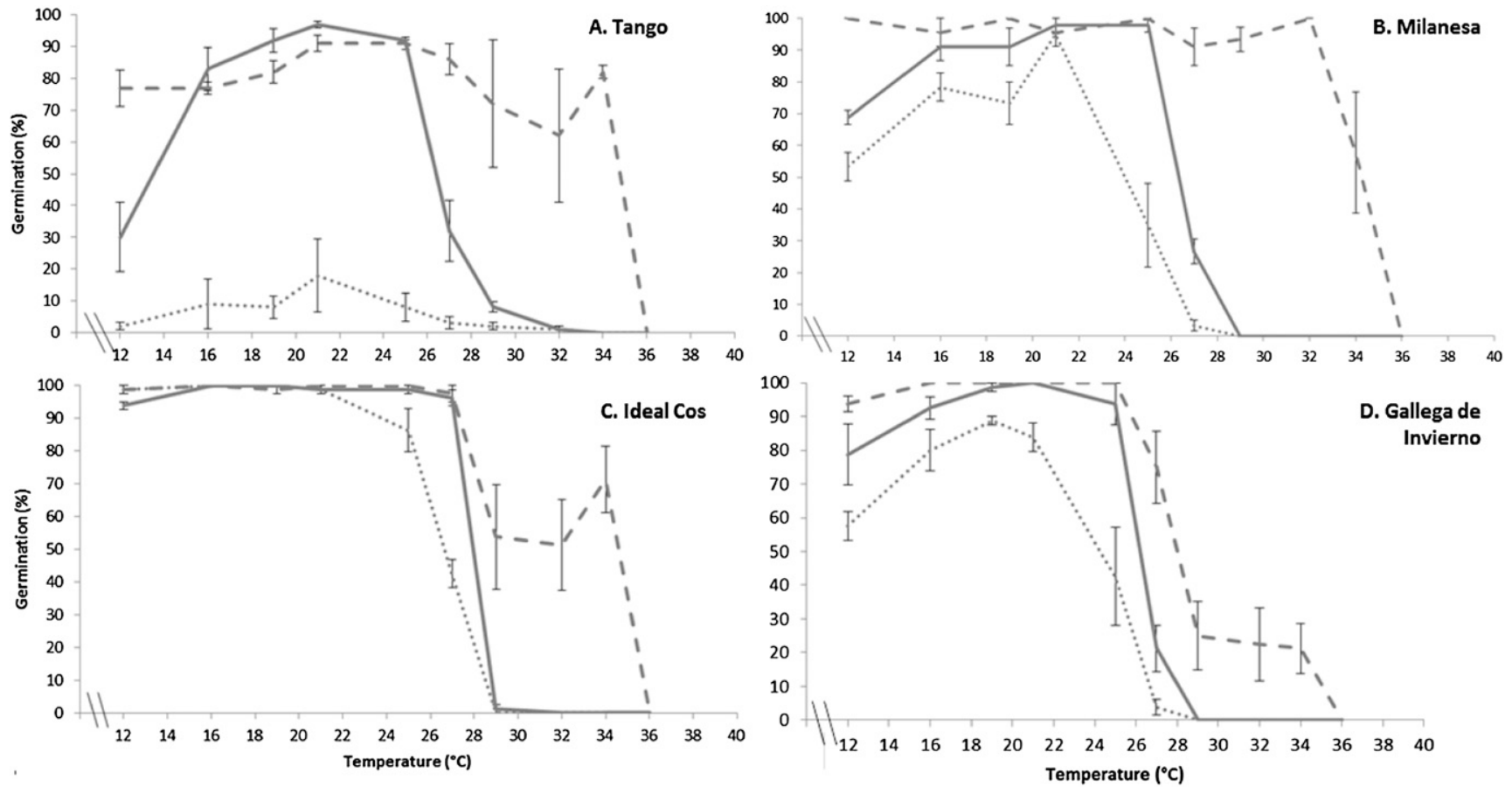

Fig. 4. Germination percentage at different temperatures in darkness of (A) 'Tango', (B) 'Milanesa', (C) 'Ideal Cos', and (D) 'Gallega de Invierno' lettuce seeds treated with red light during $24 \mathrm{~h}$ at $20{ }^{\circ} \mathrm{C}$ and $98 \%$ relative humidity (solid line), priming (broken line) and untreated (dotted line). Data are means \pm se from four replicates of 25 seeds each, except in 'Milanesa' where three replicates of 20 seeds each were sown; $\left(1.8 \times{ }^{\circ} \mathrm{C}\right)+32={ }^{\circ} \mathrm{F}$.

Table 2. Standard germination ${ }^{\mathrm{z}}$, expressed as percentage of normal seedlings, of treated and control (untreated) seeds from three lettuce cultivars, before and after salt-saturated accelerated aging at $45{ }^{\circ} \mathrm{C}\left(113.0{ }^{\circ} \mathrm{F}\right)$ and $75 \%$ relative humidity.

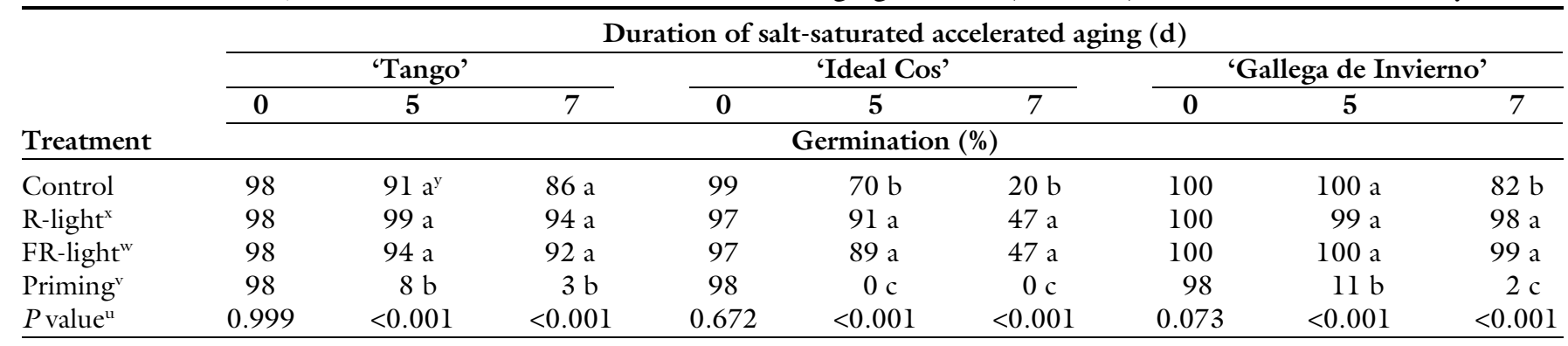

${ }^{\mathrm{z}}$ Germination of normal seedlings evaluated after $7 \mathrm{~d}$ at $20^{\circ} \mathrm{C}\left(68.0^{\circ} \mathrm{F}\right)$ and light.

${ }^{y}$ Means in the same column with different letter(s) are significantly different according to least significant difference test $(\alpha=0.05)$.

${ }^{x}$ Red light treatment: 24 h at $98 \%$ relative humidity under red light.

wFar-red light treatment: 24 h at $98 \%$ relative humidity under far-red light.

"Priming treatment: $48 \mathrm{~h}$ in $-1.25 \mathrm{MPa}(12.5 \mathrm{bar})$ solution at $20^{\circ} \mathrm{C}$ and fluorescent light.

"Probability value from analysis of variance.

different periods of accelerated aging (Fig. 5). Results of this experiment confirm the positive effect of $\mathrm{R}$ - and FR-light treatments on seed longevity. However, in general, the benefit did not differ with that of the dark treatment, indicating that the effect on longevity of this group of treatments would not be related with light, but with the controlled hydration and subsequent drying of the seed. The importance of seed drying on different aspects of seed quality, including longevity, has been reported (Hay and Probert, 1995; Navratil and Burris, 1984; Schwember and Bradford, 2005). In the case of lettuce, seed drying occurs in the field under uncontrolled conditions. Results of this study suggest that a partial hydration of seeds up to a $16 \%$ water content and drying at controlled conditions has an effect in extending seed longevity. Physiological mechanisms explaining this effect deserve future investigation.

In conclusion, the proposed treatment of irradiating partially hydrated seeds with $\mathrm{R}$ light has a positive effect on alleviation of photoblasticity in lettuce. Compared with priming, this is a simpler treatment that also improves seed longevity; however, priming effects on alleviation of seed photoblasticity and thermoinhibition at temperatures over $25^{\circ} \mathrm{C}$ are greater. 


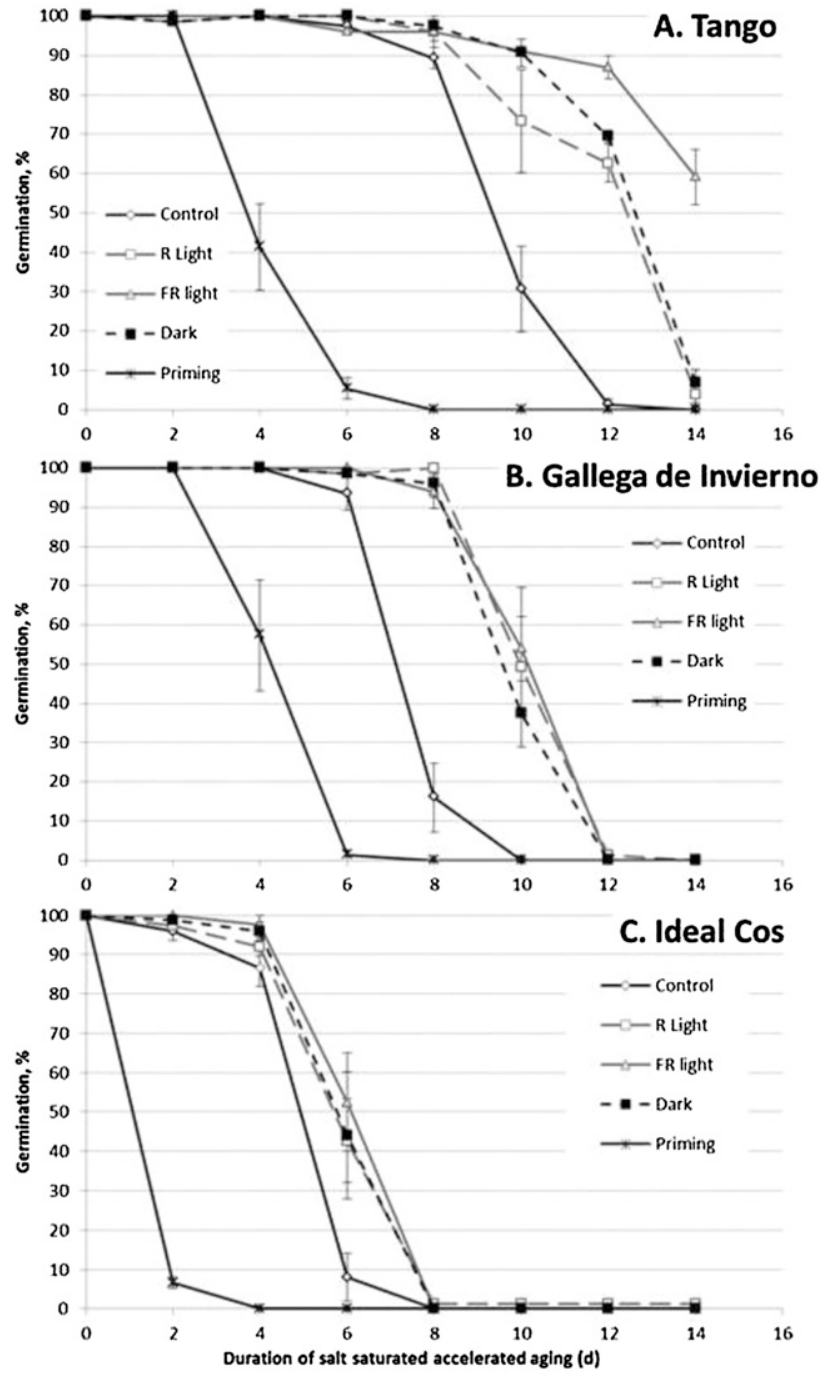

Fig. 5. Seed physiological germination at $20^{\circ} \mathrm{C}\left(68.0^{\circ} \mathrm{F}\right)$ and light of three lettuce cultivars after different periods of salt-saturated accelerated aging at $45^{\circ} \mathrm{C}\left(113.0^{\circ} \mathrm{F}\right)$ and $75 \%$ relative humidity $(\mathrm{RH})$. Control $=$ untreated seeds, $\mathrm{R}$ Light $=$ seeds treated under red light at $98 \% \mathrm{RH}$ for $24 \mathrm{~h}$, FR Light = seeds treated under far-red light at $98 \% \mathrm{RH}$ for $216 \mathrm{~h}$, Dark = seeds treated at $98 \% \mathrm{RH}$ in darkness for $24 \mathrm{~h}$, Priming = seeds treated in $-1.25 \mathrm{MPa}$ (12.5 bar) solution with fluorescent light for $48 \mathrm{~h}$. All treatments were performed at $20^{\circ} \mathrm{C}$. After each treatment, seeds were dried at $30{ }^{\circ} \mathrm{C}\left(86.0^{\circ} \mathrm{F}\right)$ for $90 \mathrm{~min}$. Data are means $\pm \mathrm{SE}$ from four replicates of 25 seeds each.

Benefit of the R-light treatment in seed longevity was similar to the effect of similar treatments using FR light or no-light (in darkness), so this effect would not be associated to photoblasticity alleviation or imposition, but to the controlled hydration and drying of the seeds.

\section{Literature cited}

Bewley, D., H. Hilhorst, K. Bradford, and H. Nogogaki. 2013. Seeds: Physiology of development, germination and dormancy. 3rd ed. Springer, New York, NY.
Contreras, S., M. Bennett, J. Metzger, and D. Tray. 2008. Maternal light environment during seed development affects lettuce seed weight, germinability and storability. HortScience 43:845852 .

Contreras, S., M. Bennett, J. Metzger, D. Tray, and H. Nerson. 2009. Red to farred ratio during seed development affects lettuce seed germinability and longevity. HortScience 44:130-134.

Coolbear, P., P.E. Toledo, and U. Seetagoses. 1992. Effects of temperature of pre-sowing hydration treatment and subsequent drying rates on the germination performance of celery seed. N. Z. J. Crop Hort. Sci. 19:9-14.

Cresswell, E.G. and J.P. Grime. 1981. Induction of a light requirement during seed development and its ecological consequences. Nature 291:583-585.

Doroszewski, A. 1997. Natural far red irradiation and weed seed persistence in the soil, p. 297-302. In: R.H. Ellis, M. Black, A.J. Murdoch, and T.D. Hong (eds.). Basic and applied aspects of seed biology. Kluwer Academic Publishers, Dordrecht, The Netherlands.

Górski, T., K. Górska, and H. Stasiak. 2013. Inhibition of seed germination bay far red radiation transmitted through leaf canopies. Polish J. Agron. 13:10-38.

Górski, T. and J. Rybicki. 1985. Daleka czerwien jako czynnik zwiekszajacy zywotnosc nasion w glebie. Pamietnik Pulawski 85:29-40.

Hay, F.R. and R.J. Probert. 1995. Seed maturity and the effects of different drying conditions on desiccation tolerance and seed longevity in foxglove (Digitalis purpurea L.). Ann. Bot. (Lond.) 76:639647.

Hayes, R.G. and W.H. Klein. 1974. Spectral quality influence of light during development of Arabidopsis thaliana plants in regulating seed germination. Plant Cell Physiol. 15:643-653.

Heydecker, W., J. Higgins, and R. Gulliver. 1973. Accelerated germination by osmotic seed treatment. Nature 246: $42-44$.

Capron, I., F. Corbineau, F. Dacher, C. Job, D. Côme, and D. Job. 2000. Sugarbeet seed priming: Effects of priming conditions on germination, solubilization of 11-S globulin and accumulation of LEA proteins. Seed Sci. Res. 10:243254.

Chojnowski, M., F. Corbineau, and D. Come. 1997. Physiological and biochemical changes induced in sunflower seeds by osmopriming and subsequent drying, storage and aging. Seed Sci. Res. 7:323331 .
Hill, H.J. 1999. Recent developments in seed technology. J. New Seeds 1:105112 .

Hsiao, A. and W. Vidaver. 1971. Seed water content in relation to phytochromemediated germination of lettuce seeds (Lactuca sativa L. var. Grand Rapids). Can. J. Bot. 49:111-115.

International Seed Testing Association. 2011. International rules for seed testing. ISTA, Bassersdorf, Switzerland. 
Kendrick, R. and J. Russell. 1975. Photomanipulation of phytochrome in lettuce seeds. Plant Physiol. 56:332-334.

Maguire, J. 1962. Speed of germinationAid in selection and evaluation of seedling emergence evaluation and vigor. Crop Sci. 2:176-177.

Michel, B. 1983. Evaluation of the water potentials of solutions of polyethylene glycol 8000 both in absence and presence of other solutes. Plant Physiol. 72:66-70.

Nascimento, W. 2003. Preventing thermoinhibition in a thermosensitive lettuce genotype by seed imbibitions at low temperature. Sci. Agr. 60:447-480.

Navratil, R.J. and J.S. Burris. 1984. The effect of drying temperature on corn seed quality. Can. J. Plant Sci. 64:487-496.

Pimentel, I. 2013. Red and far-red light treatments to modify thermoinhibition, photoblasticity and longevity in lettuce seeds. Pontificia Universidad Católica de Chile, Santiago, Chile, MS Thesis.

Powell, A., L. Yule, H. Jing, S.P.C. Groot, R.J. Bino, and H.W. Pritchard. 2000. The influence of aerated hydration seed treatment on seed longevity as assessed by the viability equations. J. Expt. Bot. 353:20312043.

Schwember, A. and K. Bradford. 2005. Drying rates following priming affect temperature sensitivity of germination and longevity of lettuce seeds. HortScience 40:778-781.

Schwember, A. and K. Bradford. 2010. A genetic locus and gene expression patterns associated with the priming effect on lettuce seed germination at elevated temperatures. Plant Mol. Biol. 73:105118.

Seo, M., E. Nambara, G. Choi, and S. Yamaguchi. 2009. Interaction of light and hormone signals in germinating seeds. Plant Mol. Biol. 69:463-472.

Smith, O.E., N.C. Welch, and O.D. McCoy. 1973. Studies on lettuce seed quality: II. Relationship of seed vigor to emergence, seedling weight, and yield. J. Amer. Soc. Hort. Sci. 98:552-556.

Sung, Y., D. Cantliffe, R. Nagata, and N. Nascimento. 2008. Structural changes in lettuce seed during germination at high temperature altered by genotype, seed maturation temperature, and seed priming. J. Amer. Soc. Hort. Sci. 133:300-311.

Tarquis, A. and K. Bradford. 1992. Prehydration and priming treatments that advance germination also increase the rate of deterioration of lettuce seeds. J. Expt. Bot. 43:307-317.

Valdes, V.M. and K.J. Bradford. 1987. Effects of seed coating and osmotic priming on the germination of lettuce seeds. J. Amer. Soc. Hort. Sci. 112:153-156.

Valdes, V.M., K.J. Bradford, and K.S. Mayberry. 1985. Alleviation of thermodormancy in coated lettuce seeds by seed priming. HortScience 20:1112-1114.

Vertucci, C., F. Vertucci, and C. Leopold. 1987. Water content and the conversion of phytochrome regulation of lettuce dormancy. Plant Physiol. 84:887-890.

Wien, H. 1997. Lettuce, p. 479-509. In: H.C. Wien (ed.). The physiology of vegetable crops. CABI Publ., Wallingford, England.

Winston, P. and B. Bates. 1960. Saturated solutions for the control of humidity in biological research. Ecology 41:232-237. 